\title{
Asexual-sexual morph connection in the type species of Berkleasmium
}

\author{
Joey Tanney ${ }^{1}$, and Andrew N. Miller ${ }^{2}$
}

1Biodiversity (Mycology \& Botany), Eastern Cereal and Oilseed Research Centre, Agriculture and Agri-Food Canada, Ottawa, ON K1A 0C6, Canada; corresponding author e-mail: jtanney@lakeheadu.ca

${ }^{2}$ University of Illinois at Urbana-Champaign, Illinois Natural History Survey, 1816 South Oak Street, Champaign, IL 61820, USA

Abstract: Berkleasmium is a polyphyletic genus comprising 37 dematiaceous hyphomycetous species. In this study, independent collections of the type species, B. concinnum, were made from Eastern North America. Nuclear internal transcribed spacer rDNA (ITS) and partial nuc 28S large subunit rDNA (LSU) sequences obtained from collections and subsequent cultures showed that Berkleasmium concinnum is the asexual morph of Neoacanthostigma septoconstrictum (Tubeufiaceae, Tubeufiales). Phylogenies inferred from Bayesian inference and maximum likelihood analyses of ITS-LSU sequence data confirmed this asexual-sexual morph connection and a re-examination of fungarium reference specimens also revealed the co-occurrence of $N$. septoconstrictum ascomata and $B$. concinnum sporodochia. Neoacanthostigma septoconstrictum is therefore synonymized under $B$. concinnum on the basis of priority. A specimen identified as $N$. septoconstrictum from Thailand is described as $N$. thailandicum sp. nov., based on morphological and genetic distinctiveness.
Key words: Ascomycota molecular systematics morphology new species taxonomy Tubeufia Tubeufiales

Article info: Submitted: 16 February 2017; Accepted: 26 April 2017; Published: 3 May 2017.

\section{INTRODUCTION}

Naturalist Thomas Gibson Lea botanized extensively in Ohio until his death in 1844, after which his fungal specimens were sent to his correspondent Miles J. Berkeley (Lea 1849). Berkeley (1845) described Sporidesmium concinnum ("A very pretty object under the microscope") from Lea's specimen growing on dead wood from a rotten tree trunk (host unknown) in Ohio. Zobel (in Corda 1854) later described the new genus Berkleasmium to accommodate $S$. concinnum, illegitimately devising the name Berkleasmium cordeanum. More than one century later, Moore (1958) re-established the generic name Berkleasmium to accommodate sporodochial species previously placed in Sporidesmium, later accepting ten species (Moore 1959). Berkleasmium currently comprises 37 species characterized by sporodochial conidiomata bearing macronematous conidiophores and monoblastic conidiogenous cells that give rise to brown or black, dry, rhexolytically-seceding, dictyoconidia (Ellis 1971, Bussaban et al. 2001, Seifert et al. 2011, http://www.speciesfungorum. org/). Berkleasmium species are associated with a variety of decaying above-ground tissues of monocot and dicot plants from terrestrial and aquatic habitats. No known sexual morph has yet been connected to Berkleasmium.

Available sequences in GenBank are restricted to species described from Thailand or Micronesia, including Berkleasmium crunisia, B. micronesicum, B. nigroapicale, and $B$. typhae. Previous phylogenetic analyses based on SSU and LSU sequences of these species indicate the polyphyly of Berkleasmium, with $B$. micronesicum and B. nigroapicale placed incertae sedis sister to Sporormiaceae, and B. crunisia and B. typhae placed incertae sedis sister to Mycopepon smithii (Pinnoi et al. 2007, Wang et al. 2007, Hyde et al. 2016). This polyphyly is not surprising given the treatment of Berkleasmium as a genus characterised by the sporodochia bearing dark brown dictyoconidia. For example, Monodictys monilicellularis was transferred to Berkleasmium because of sporodochia formation, despite the presence of distinctive sterile moniliform appendages, while $B$. papillatum was placed within the genus despite proliferating conidiophores; the taxonomic informativeness of these characters remains to be tested by molecular phylogenetic analyses (Raghuveer Rao \& Rao 1964, Whitton et al. 2012).

Determining the phylogenetic placement of the type species, B. concinnum, is crucial to delineate taxonomic boundaries within this polyphyletic and morphologically heterogeneous genus. In this study, ITS and LSU sequences were analyzed with other taxa in Tubeufiales to estimate phylogenetic relationships.

\section{MATERIALS AND METHODS}

\section{Sampling and isolation of fungi}

Field collections of Berkleasmium concinnum were made independently in Gatineau, Quebec, Canada and the Great Smoky Mountains National Park, North Carolina and Tennessee, USA. Single conidium cultures were generated by transferring individual conidia to $6 \mathrm{~cm}$ diam Petri dishes containing MEA using an electrolytically sharpened tungsten needle (Brady 1965). Conidial germination was visually verified and cultures were incubated at $16{ }^{\circ} \mathrm{C}$ under $12: 12$

\section{2017 International Mycological Association}

You are free to share - to copy, distribute and transmit the work, under the following conditions:

Attribution: $\quad$ You must attribute the work in the manner specified by the author or licensor (but not in any way that suggests that they endorse you or your use of the work).

Non-commercial: $\quad$ You may not use this work for commercial purposes.

No derivative works: You may not alter, transform, or build upon this work.

For any reuse or distribution, you must make clear to others the license terms of this work, which can be found at http://creativecommons.org/licenses/by-nc-nd/3.0/legalcode. Any of the above conditions can be waived if you get permission from the copyright holder. Nothing in this license impairs or restricts the author's moral rights. 
h dark:light conditions. Specimens were accessioned in the Canadian National Mycological Herbarium (Ottawa, Canada; DAOM) or the Illinois Natural History Survey Fungarium (Champaign, USA; ILLS) and living cultures were deposited in the Canadian Collection of Fungal Cultures (Ottawa, Canada; DAOMC).

\section{Morphological observations}

Conidiomata and ascomata from fresh and dried specimens were mounted in deionized water, $5 \% \mathrm{KOH}$, or lactic acid. Observations were made using an Olympus BX50 light microscope (Olympus, Tokyo) and an Olympus SZX12 stereomicroscope and micrographs were captured using an InfinityX-32 camera (Lumenera, Ottawa) and Infinity Analyze (Lumenera) software. Photographic plates were assembled using Adobe Photoshop 5.5 (Adobe Systems, San Jose, CA).

\section{DNA extraction, PCR amplification, and sequencing}

Total genomic DNA was extracted from 12-wk-old cultures or directly from conidiomata of $B$. concinnum using the Ultraclean Microbial DNA Isolation Kit (Mo Bio Laboratories, Carlsbad, CA) or NucleoSpin Plant II Kit (Macherey-Nagel, Düren, Germany) following the manufacturers' protocol. The entire ITS and the first two domains of LSU were amplified and sequenced following the methods of Promputtha \& Miller (2010) and Tanney et al. (2015).

\section{Phylogenetic analyses}

Sequence contigs were assembled and trimmed using Geneious R8 v. 8.1.5 (Biomatters, Auckland, New Zealand). ITS and LSU sequences were concatenated to create a dataset containing 37 sequences that was aligned using MAFFT v. 7 (Katoh \& Standley 2013) and visually inspected in Geneious. The most suitable sequence evolution model $(G T R+\mid+G)$ was determined based on the optimal Akaike information criterion scores in MrModeltest v. 2.2.6 (Nylander 2004). The ex-type culture of Botryosphaeria corticis (CBS119047; NR 111213) was selected as outgroup based on previous analyses (Sanchez et al. 2012). Bayesian inference (BI) phylogenetic reconstruction was performed with MrBayes v. 3.2 (Ronquist et al. 2012). Three independent Markov Chain Monte Carlo (MCMC) samplings were performed with 12 chains (11 heated and one cold) with sampling every 500 generations until the standard deviation of split frequencies reached a value $<0.01$. The first $25 \%$ of trees were discarded as burn-in and the remaining trees kept and combined into one $50 \%$ majority rule consensus tree. Convergence was assessed from the three independent runs using Tracer v. 1.6 (Rambaut et al. 2014). Maximum likelihood (ML) analysis was performed using RAxML v. 8.2.4 (Stamatakis 2014) in PAUP v. 4.0 b10 (Swofford 2003) starting from a random starting tree with 1000 bootstrap replicates. Consensus trees were visualized in FigTree 1.4.2 (available at http://tree.bio.ed.ac. uk/software/figtree/) and exported as SVG vector graphics for assembly in Adobe Illustrator v10 (Adobe Systems, San Jose, CA). All novel sequences used in this study were accessioned in GenBank (Table 1) and taxonomic novelties and associated metadata were deposited in MycoBank (www. mycobank.org).

\section{RESULTS}

The concatenated ITS-LSU alignment consisted of 37 sequences and 1277 positions. All Berkleasmium concinnum specimens shared identical ITS sequences except for a single A-to-G transition (position 441 in alignment) in specimen ILLS 80804. Berkleasmium concinnum ITS sequences were identical to the ITS sequence of the holotype of Neoacanthostigma septoconstrictum (ILLS 59356), except for the single bp difference in ILLS 80804. LSU sequences for all Berkleasmium concinnum isolates were identical and $99 \%$ similar to the $N$. septoconstrictum type (ILLS 59356; NR_119758), with one A-to-T transversion (position 758) and two C-to-T transitions (positions 806 and 1213).

Phylogenies inferred from $\mathrm{BI}$ and $\mathrm{ML}$ analyses were generally concordant. However, the backbone topology was polytomous in the $\mathrm{BI}$ analysis versus dichotomous in the $\mathrm{ML}$ analysis, albeit with low-supported branch nodes in both analyses. The placement of Acanthostigma filiforme was also discordant among both analyses, probably a result of the poorly-supported backbone, and PP values were generally higher than BS values. Berkleasmium concinnum and $N$. septoconstrictum, including the type species $N$. fusiforme (MFLUCC 110510; KF301529) and a specimen identified as $N$. septoconstrictum (MFLUCC 151248; KX454176) but with a distinct ITS sequence, formed a wellsupported clade in both analyses (BS = 93; PP =1) (Fig. 1). The Berkleasmium-Neoacanthostigma clade was weaklysupported $(B S=37 ; \mathrm{PP}=0.57$ ) sister to a clade comprising Helicoma conicodentatum, Helicosporium linderi, Tubeufia khunkornensis, and a strain identified as Chlamydotubeufia cf. huaikangplaensis.

Sequence similarity and ITS-LSU phylogenetic analyses reveal that $B$. concinnum is the asexual morph of $N$. septoconstrictum (Tubeufiaceae, Tubeufiales) and that the type species of both genera occur in a well-supported clade $(B S=100 ; P P=1)$. Although not originally reported with the description of $N$. septoconstrictum (Promputtha \& Miller 2010), re-examination of the type specimen revealed numerous conidiomata of $B$. concinnum covering the woody substrate along with ascomata of $N$. septoconstrictum. Examining additional reference specimens of $B$. concinnum confirmed the co-occurrence of the ascomatal sexual morph (i.e. N. septoconstrictum) among the asexual $B$. concinnum conidiomata (DAOM 24916, DAOM 29377, DAOM 41029, DAOM 75764, DAOM 155883, DAOM 155884, DAOM 210103, ILLS 80802; Fig. 2 A-C). Since Berkleasmium Zobel 1854 is an earlier name than Neoacanthostigma Boonmee et al. 2014, N. septoconstrictum must be synonymized under $B$. concinnum, on the assumption that all priority currently accorded to generic names typified by a sexual morph is ended in July 2017. In addition, the specimen previously identified by Hyde et al. (2016) as $N$. septoconstrictum (MFLUCC 15-1248; KX454176) is not conspecific with the type specimen of this species (ILLS59356; NR119758) based on asexual morph dissimilarity (hyaline helicoid conidia) and genetic (13\% ITS sequence divergence) differences and is therefore described as a new species, $N$. thailandicum. 


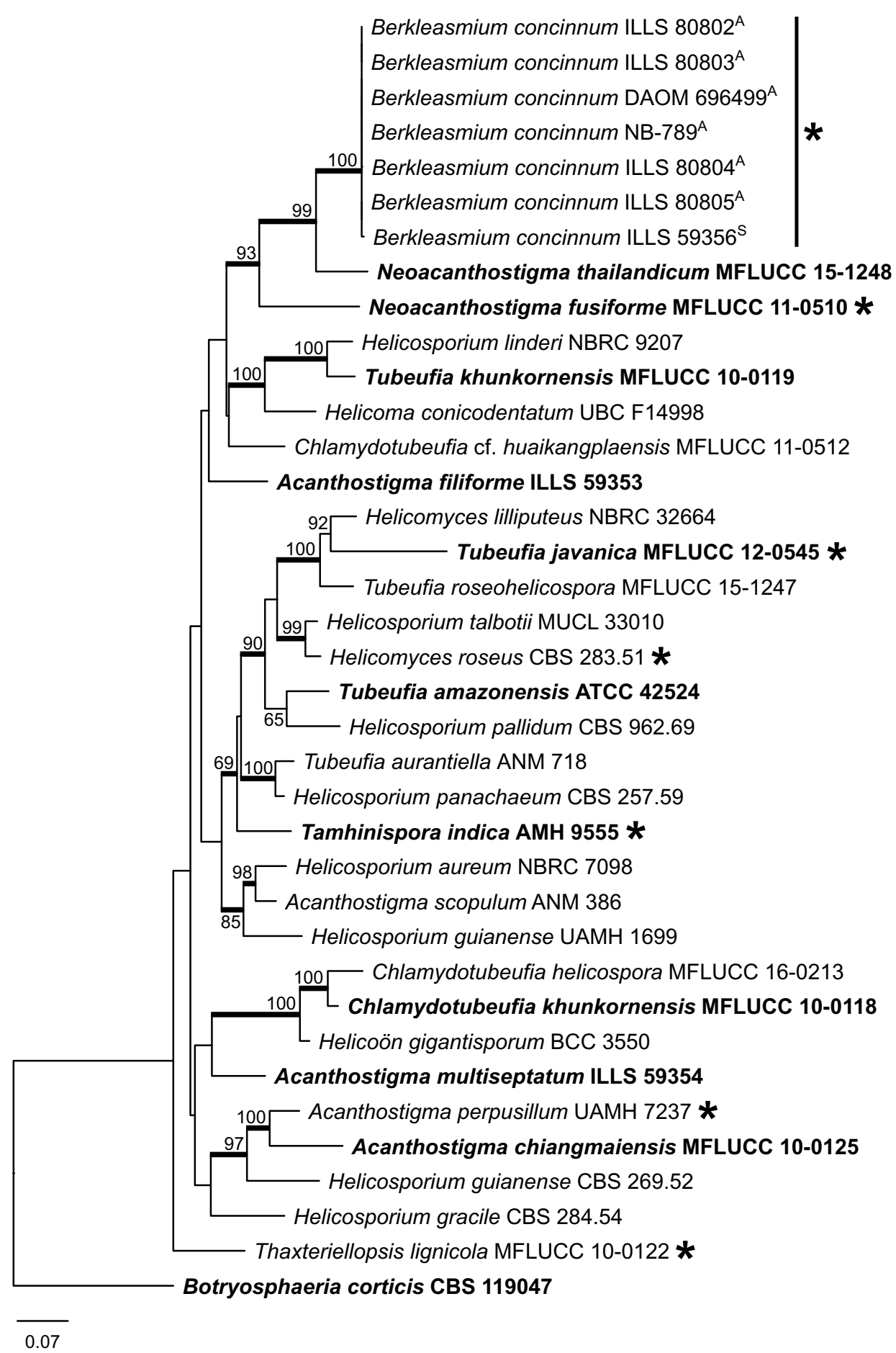

Fig. 1. Most likely tree from a RAxML analysis of ITS-LSU dataset containing representative Tubeufiales species. Culture collection accession numbers or specimen identifiers follow the species name, with type or ex-type strains in bold and asterixes $\left({ }^{*}\right)$ denoting generic types. ${ }^{A}$ denotes sequences derived from Berkleasmium concinnum asexual morph and ${ }^{s}$ denotes sequences derived from $B$. concinnum sexual morphs. RAxML bootstrap support percentages $\geq 50$ from a summary of 1000 replicates are presented at the branch nodes. Thickened branches indicate Bayesian posterior probability values $\geq 0.95$. The tree was rooted with Botryosphaeria corticis and the scale bar represents the number of substitutions per site.

\section{TAXONOMY}

Berkleasmium concinnum (Berk.) S. Hughes, Canad. J. Bot. 36: 740 (1958).

(Fig. 2; Promputtha \& Miller 2010: figs 15-22)

Basionym: Sporidesmium concinnum Berk., London J. Bot.
Synonyms: Berkleasmium cordeanum Zobel, in Corda, Icon. Fung. 6: 4 (1854); nom. illegit. (Art. 52.1).

Neoacanthostigma septoconstrictum (Promp. \& A.N. Mill.) S. Boonmee \& K.D. Hyde, Fungal Diversity 68: 279 (2014). Acanthostigma septoconstrictum Promp. \& A.N. Mill., Mycologia 102: 579 (2010). 
Type: USA: Ohio: on dead wood, T.G. Lea 168 (K(M) holotype, n.v.; K(M)-IMI94327 - slide ex-holotype).

Other specimens examined: Canada: Quebec: Gatineau, Aylmer, Boucher Forest, on large, rotten, decorticated hardwood log, 17 Jul. 2015, J.B. Tanney (DAOM 696473); ibid., 29 Aug. 2015, J.B. Tanney (DAOM 696486); ibid., 10 Jul. 2015, J.B. Tanney (DAOM 696499, DAOMC 251512, DAOMC 251513); ibid., fallen hardwood log, 5 Sep. 2016, J.B. Tanney (NB-789). - Russia: Primorsky Krai, Khasansky District, Kedrovaya Pad Nature Preserve, log of an unknown deciduous species, 3 Oct. 1987, I.M. Bacuebeba (DAOM 210103). - USA: Louisiana: St. Tammany Parish, Honey Island Swamp near Pearl River, rotten wood, 6 Jun. 1976, S.J. Hughes (DAOM 155883); ibid., 6 Jun. 1976, W.B. Cooke (DAOM 155884). Massachusetts: Salem, on Salix wood, 1834 (DAOM 43686). Missouri: St Louis County, Benbush, on dead wood, 15 Nov. 1941, G.D. Darker (DAOM 75764). New York: Flatbush, 1890, I.L. Zabriskie (DAOM 34307); Lloyd-Cornell Preserve, Ringwood, on rotten wood, 6 Sep. 1952, S.J. Hughes (DAOM 29052, DAOM 29377); ibid., on decorticated wood (old), 6 Sep. 1952, W.I. IIIman (DAOM 239154);

Table 1. Sequences used in phylogenetic analyses in this study.

\begin{tabular}{|c|c|c|c|}
\hline \multirow[t]{2}{*}{ Species } & \multirow[t]{2}{*}{ Specimen/strain } & \multicolumn{2}{|c|}{ GenBank No. } \\
\hline & & ITS & LSU \\
\hline Acanthostigma chiangmaiense & MFLUCC $10-0125^{\top}$ & JN865209 & JN865197 \\
\hline Acanthostigma filiforme & ILLS $59353^{\top}$ & GQ856146 & GQ850494 \\
\hline Acanthostigma multiseptatum & ILLS 59354 & NR_119759 & GQ850492 \\
\hline Acanthostigma perpusillum & UAMH 7237 & AY916492 & AY856892 \\
\hline Acanthostigma scopulum & ANM 386 & GQ856141 & GQ850489 \\
\hline Berkleasmium concinnum & ILLS 59356(T) & NR_119758 & NG_042520 \\
\hline Berkleasmium concinnum & DAOM 696499 & KY611397 & KY611399 \\
\hline Berkleasmium concinnum & NB-789 & KY611398 & KY611400 \\
\hline Berkleasmium concinnum & ILLS 80802 & \multicolumn{2}{|c|}{ KY582484 } \\
\hline Berkleasmium concinnum & ILLS 80803 & \multicolumn{2}{|c|}{ KY582485 } \\
\hline Berkleasmium concinnum & ILLS 80804 & \multicolumn{2}{|c|}{ KY582486 } \\
\hline Berkleasmium concinnum & ILLS 80805 & \multicolumn{2}{|c|}{ KY582487 } \\
\hline Botryosphaeria corticis & CBS $119047^{\mathrm{T}}$ & NR_111213 & NG_042457 \\
\hline Chlamydotubeufia cf. huaikangplaensis & MFLUCC 11-0512 & KF301528 & KF301536 \\
\hline Chlamydotubeufia helicospora & MFLUCC $16-0213^{\top}$ & KX454169 & KX454170 \\
\hline Chlamydotubeufia khunkornensis & MFLUCC $100118^{\top}$ & NR_137588 & JN865190 \\
\hline Helicoma conicodentatum & UBC F14998 & AY916450 & AY856869 \\
\hline Helicomyces lilliputeus & NBRC 32664 & AY916483 & AY856899 \\
\hline Helicomyces roseus & CBS 283.51 & AY916464 & AY856881 \\
\hline Helicoön gigantisporum & BCC 3550 & AY916467 & AY856904 \\
\hline Helicosporium aureum & NBRC 7098 & AY916478 & AY856894 \\
\hline Helicosporium gracile & CBS 284.54 & AY916485 & AY916086 \\
\hline Helicosporium guianense & UAMH 1699 & AY916479 & AY856891 \\
\hline Helicosporium guianense & CBS 269.52 & AY916487 & AY856893 \\
\hline Helicosporium linderi & NBRC 9207 & AY916454 & AY856895 \\
\hline Helicosporium pallidum & CBS 962.69 & AY916460 & AY856886 \\
\hline Helicosporium panachaeum & CBS 257.59 & AY916471 & AY916087 \\
\hline Helicosporium talbotii & MUCL 33010 & AY916465 & AY856874 \\
\hline Neoacanthostigma fusiforme & MFLUCC $11-0510^{\top}$ & KF301529 & KF301537 \\
\hline Neoacanthostigma thailandicum & MFLUCC $15-1248^{\top}$ & KX454176 & - \\
\hline Tamhinispora indica & AMH $9555^{\top}$ & NR_137801 & KC469283 \\
\hline Thaxteriellopsis lignicola & MFLUCC 10-0122 & JN865206 & JN865194 \\
\hline Tubeufia amazonensis & ATCC $42524^{\top}$ & AY916458 & AY856911 \\
\hline Tubeufia aurantiella & ANM 718 & GQ856140 & GQ850485 \\
\hline Tubeufia javanica & MFLUCC $12-0545^{\top}$ & KJ880034 & KJ880036 \\
\hline Tubeufia khunkornensis & MFLUCC 10-0119 & JN865203 & JN865191 \\
\hline Tubeufia roseohelicospora & MFLUCC 15-1247 & KX454177 & KX454178 \\
\hline
\end{tabular}

New sequences generated in this study are in bold, ' denotes sequence from type or ex-type material, (T) refers to the holotype of Neoacanthostigma septoconstrictum, not B. concinnum. 


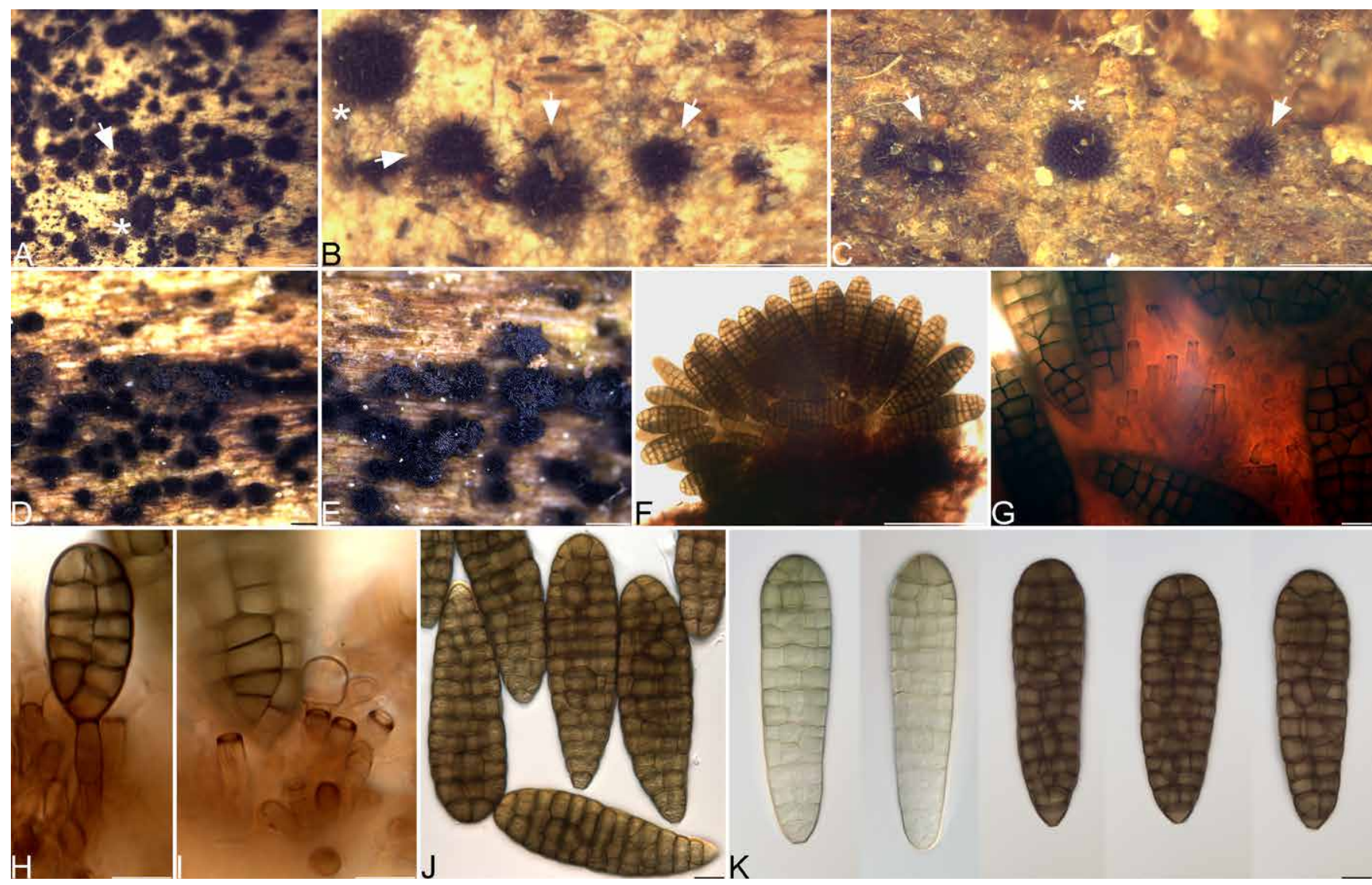

Fig. 2. Berkleasmium concinnum conidiomata and ascomata. A-C. Co-occurring ascomata and sporodochia, arrows point to ascomata and asterisks $\left(^{*}\right)$ denote sporodochia. D-E. Sporodochia in situ. F. Sporodochium. G-I. Conidiogenous cells. J. Conidia mounted in $\mathrm{H}_{2} \mathrm{O}$. $\mathbf{K}$. Developing and mature conidia mounted in lactic acid. A-C DAOM 696473, D-H NB-789, I-J DAOM 155884, K DAOM 155883. Bars: A-E = 500 $\mu \mathrm{m}, \mathrm{F}=100 \mu \mathrm{m}, \mathrm{G}-\mathrm{K}=10 \mu \mathrm{m}$.

Buffalo, G.W. Clinton (DAOM 34362). North Carolina: Haywood Co., Great Smoky Mountains National Park, Big Creek, Baxter Creek Trail, $35.7485^{\circ} \mathrm{N},-83.1119^{\circ} \mathrm{W}, 610 \mathrm{~m}$ elev., decorticated $3 \mathrm{~cm}$ diam branch on ground, 16 Jun. 2007, A.N. Miller et al. (ANM 1141, ILLS 80802); Cullowhee, on rotten wood, Jun. 1887, R. Thaxter (DAOM 29026). South Carolina: on wood, (DAOM 34361). Tennessee: Blount County, Bote Mountain, Great Smoky Mountains National Park, on rotten wood and bark, 23 Aug. 1977, S.J. Hughes (DAOM 188987, DAOM 169302); Cocke County, Great Smoky Mountains National Park, Cosby, Low Gap Trail, $35.7539^{\circ} \mathrm{N}, 83.2071^{\circ} \mathrm{W}, 716$ m elev., decorticated wood on ground, 15 Jul. 2005, A.N. Miller \& A.M. Stchigel (ANM536.1, ILLS 59356 - holotype of Acanthostigma septoconstrictum); ibid., decorticated $5 \mathrm{~cm}$ diam. branch on ground, 3 Nov. 2007, A.N. Miller et al. (ANM 1407, ILLS 80805); ibid., Cosby Nature Trail, $35.7538^{\circ} \mathrm{N}, 83.2072^{\circ} \mathrm{W}, 716 \mathrm{~m}$ elev., $50 \mathrm{~cm}$ diam log on ground, 20 May 2008, A.N. Miller et al. (ANM 1701, ILLS 80806); Sevier Co., Great Smoky Mountains National Park, 5 miles east of Gatlinburg, Greenbrier, Old Settlers Trail, $35.7076^{\circ} \mathrm{N}, 83.3804^{\circ}$ W, $457 \mathrm{~m}$ elev., decorticated $6 \mathrm{~cm}$ diam branch on ground, 19 Jun. 2007, A.N. Miller et al. (ANM 1171, ILLS 80803); Twin Creeks, Twin Creeks Nature Trail, near ATBI plot, $35.6881^{\circ} \mathrm{N}, 83.4999^{\circ} \mathrm{W}, 549 \mathrm{~m}$ elev., decorticated $5 \mathrm{~cm}$ diam branch on ground, 18 Jun. 2007, A.N. Miller et al. (ANM 1227, ILLS 80804). West Virginia: Giles County, Mountain Lake, on well decayed log of deciduous tree, 2 Sep. 1936, D.H. Linder (DAOM 24916); Nuttallburg, Nov. 1893, on rotten wood, L.W. Nuttall (DAOM 34290). Wisconsin: Devil's Lake near Madison, 4 Sep. 1953, R.F. Cain (DAOM 41029).
Neoacanthostigma thailandicum Tanney \& A.N. Mill. sp. nov.

MycoBank MB819966

Etymology: Named for the country where the type specimen was collected.

Diagnosis: Neoacanthostigma thailandicum is distinguished from all other species in the genus by macronematous conidiophores and larger, pale brown to brown, multi-septate conidia (to $920 \mu \mathrm{m}$ long).

Description: For a complete description of this taxon see Hyde et al. (2016: 125; N. septoconstrictum MFLU 16-1134).

Type: Thailand: Prachuap Khiri Khan, Bang Sapan, Ron Thai, on decaying wood in flowing freshwater stream, $30 \mathrm{Jul}$. 2015, K.D. Hyde KHO2 (MFLU 16-1134 - holotype, n.v.; BBH 41051 - isotype, n.v.; MFLUCC 15-1248, TBRC - cultures ex-type).

Illustration: Hyde et al. (2016: fig. 76).

Notes: Neoacanthostigma thailandicum (MFLU 16-1134) was identified as $N$. septoconstrictum in Hyde et al. (2016). 


\section{DISCUSSION}

Both ITS and LSU sequences confirm that the hyphomycete morph Berkleasmium concinnum and the pyrenomycete morph Neoacanthostigma septoconstrictum are the same species and therefore must be given a single name. Thus, $N$. septoconstrictum is synonymized under $B$. concinnum because of the priority of Berkleasmium over Neoacanthostigma. Re-examination of the $N$. septoconstrictum type specimen and additional $B$. concinnum reference specimens confirmed the frequent cooccurrence of both the asexual and sexual morphs on the same substrate, providing additional circumstantial support for this connection (Fig. $2 \mathrm{~A}-\mathrm{C}$ ).

Neoacanthostigma was proposed to accommodate a new species, $N$. fusiforme, which was chosen as the type species, along with $N$. filiforme and $N$. septoconstrictum, two species previously included in Acanthostigma but demonstrated to be phylogenetically distinct from the type species, $A$. perpusillum (Boonmee et al. 2014). Based on the ITS-LSU phylogeny presented here, the transfer of Acanthostigma filiforme to Neoacanthostigma appears unwarranted given its phylogenetic distance from $N$. fusiforme (Fig. 1). However, these two species were weakly clustered together based on the LSU phylogeny from Promputtha \& Miller (2010) and the combined ITS and LSU phylogeny from Boonmee et al. (2014). The placement of $N$. filiforme was not resolved in this study because of low support. Hyde et al. (2016) reported a helicomyces-like asexual morph for $N$. septoconstrictum based on a specimen from decaying wood in a flowing freshwater stream in Thailand; however, the ITS sequence (KX454176) of this specimen (MFLUCC 15-1248) clearly distinguishes it from the $N$. septoconstrictum type specimen [identities $=465 / 537(87 \%)$, gaps $=42 / 537(7 \%)$ ]. The ITS dissimilarity and distinctive asexual morph morphology from $B$. concinnum resulted in our description of this specimen as a novel species, $N$. thailandicum.

Tubeufiaceae (Tubeufiales) asexual morphs are morphologically diverse, containing helicosporous genera such as Helicoma, Helicomyces, Helicoön, and Helicosporium, and staurosporous genera including Araneomyces and Tetracrium (Réblová \& Barr 2000, Kodsueb et al. 2004, Tsui \& Berbee 2006). Reports of dictyosporous conidial morphs in Tubeufiaceae more reminiscent of $B$. concinnum include Chlamydotubeufia spp., Manoharachariella tectonae, Tubeufia amazonensis, and T. khunkornensis (Rossman \& Müller 1979, Boonmee et al. 2011, 2014, Rajeshkumar \& Sharma 2013, Doilom et al. 2016). The close phylogenetic relationship between $B$. concinnum and the helicosporous $N$. fusiforme and $N$. thailandicum is unexpected but supported by molecular evidence generated from independently collected and sequenced specimens and isolates. The phylogenetic placement and identification of a sexual morph for $B$. concinnum presented in this study demonstrates the significance of culturing and sequencing named-butunsequenced dematiaceous hyphomycetes.

\section{ACKNOWLEDGEMENTS}

We are grateful to Scott $A$. Redhead for nomenclatural advice and to Olga Koppel for Russian translation of the DAOM 210103 specimen label. This study was partially supported by a National Science Foundation grant (DEB-0515558) to ANM and a Natural Sciences and Engineering Research Council of Canada scholarship (PGSD2459312-2014) to JBT. JBT is grateful to the Microbiology Molecular Technologies Laboratory (MMTL) group of ORDC-AAFC, Ottawa, for processing DNA sequencing, and Keith $A$. Seifert for his comments on this manuscript.

\section{REFERENCES}

Berkeley MJ (1845) Decades of fungi. Dec. VIII.-X. London Journal of Botany 4: 298-315.

Boonmee S, Zhang Y, Chomnunti P, Chukeatirote E, Tsui CK, et al. (2011) Revision of lignicolous Tubeufiaceae based on morphological reexamination and phylogenetic analysis. Fungal Diversity 51: 63-102.

Boonmee S, Rossman AY, Liu J-K, Li W-J, Dai D-Q, et al. (2014) Tubeufiales, ord. nov., integrating sexual and asexual generic names. Fungal Diversity 68: 239-298.

Brady J (1965) A simple technique for making very fine, durable dissecting needles by sharpening tungsten wire electrolytically. Bulletin of the World Health Organization 32: 143.

Bussaban B, Lumyong S, Lumyong P, McKenzie EHC, Hyde KD (2001) A synopsis of the genus Berkleasmium with two new species and new records of Canalisporium caribense from Zingiberaceae in Thailand. Fungal Diversity 8: 73-85.

Corda ACJ (1854) Icones Fungorum hucusque cognitorum. Vol. 6. Prague: J.G. Calve.

Doilom M, Dissanayake AJ, Wanasinghe DN, Boonmee S, Liu JK, et al. (2016) Microfungi on Tectona grandis (teak) in Northern Thailand. Fungal Diversity 82: 1-76.

Ellis MB (1971) Dematiaceous Hyphomycetes. Kew: Commonwealth Mycological Institute.

Hyde KD, Hongsanan S, Jeewon R, Bhat DJ, McKenzie EHC, et al. (2016) Fungal diversity notes 367-490: taxonomic and phylogenetic contributions to fungal taxa. Fungal Diversity 80: 1-270.

Katoh K, Standley DM (2013) MAFFT multiple sequence alignment software version 7: improvements in performance and usability. Molecular Biology and Evolution 30: 772-780.

Kodsueb R, Lumyong S, Lumyong P, McKenzie EH, Ho WH, et al. (2004) Acanthostigma and Tubeufia species, including $T$. claspisphaeria sp. nov., from submerged wood in Hong Kong. Mycologia 96: 667-674.

Lea TG (1849) Catalogue of Plants, native and naturalized, collected in the vicinity of Cincinnati, Ohio, during the years 1834-1844. Philadelphia: Collins.

Moore RT (1958) Deuteromycetes I: the Sporidesmium complex. Mycologia 50: 681-692.

Moore RT (1959) The genus Berkleasmium. Mycologia 51: 734-739. Nylander J (2004) MrModeltest 2.2. Program distributed by the author, Evolutionary Biology Centre, Uppsala University, Sweden.

Pinnoi A, Jeewon R, Sakayaroj J, Hyde KD, Jones EG (2007) Berkleasmium crunisia sp. nov. and its phylogenetic affinities to the Pleosporales based on $18 \mathrm{~S}$ and $28 \mathrm{~S}$ rDNA sequence analyses. Mycologia 99: 378-384. 
Promputtha I, Miller AN (2010) Three new species of Acanthostigma (Tubeufiaceae, Dothideomycetes) from Great Smoky Mountains National Park. Mycologia 102: 574-587.

Raghuveer Rao P, Rao D (1964) “Berkleasmium” Zobel from india. Mycopathologia 22: 311-314.

Rajeshkumar K, Sharma R (2013) Tamhinispora a new genus belongs to family Tubeufiaceae from the Western Ghats, India based on morphology and phylogenetic analysis. Mycosphere 4: $165-174$.

Rambaut A (2014) FigTree v1. 4.2. University of Edinburgh, Scotland.

Reblova M, Barr ME (2000) The genus Acanthostigma (Tubeufiaceae, Pleosporales). Sydowia 52: 258-285.

Ronquist F, Teslenko M, van der Mark P, Ayres DL, Darling A, et al. (2012) MrBayes 3.2: efficient Bayesian phylogenetic inference and model choice across a large model space. Systematic Biology 61: 539-542.

Rossman A, Müller E (1979) Life history studies of Brazilian ascomycetes 6 . Three species of Tubeufia with, respectively, dictyosporous-pycnidial and helicosporous anamorphs. Sydowia 31: 180-192.

Sanchez RM, Miller AN, Bianchinotti MV (2012) A new species of Acanthostigma (Tubeufiaceae, Dothideomycetes) from the Southern Hemisphere. Mycologia 104: 223-231.

Seifert KA, Morgan-Jones G, Gams W, Kendrick B (2011) The Genera of Hyphomycetes. [Biodiversity Series no. 9] Utrecht. CBS-KNAW Fungal Biodiversity Centre.
Stamatakis A (2014) RAxML version 8: a tool for phylogenetic analysis and post-analysis of large phylogenies. Bioinformatics 30: 1312-1313.

Swofford DL (2003) PAUP*: phylogenetic analysis using parsimony (*and other methods). Version 4. Sunderland, MA: Sinaeuer Associates.

Tanney JB, Nguyen HD, Pinzari F, Seifert KA (2015) A century later: rediscovery, culturing and phylogenetic analysis of Diploöspora rosea, a rare onygenalean hyphomycete. Antonie van Leeuwenhoek 108: 1023-1035.

Tsui C, Berbee M (2006) Phylogenetic relationships and convergence of helicosporous fungi inferred from ribosomal DNA sequences. Molecular Phylogenetics and Evolution 39: 587-597.

Wang H-K, Aptroot A, Crous PW, Hyde KD, Jeewon R (2007) The polyphyletic nature of Pleosporales: an example from Massariosphaeria based on rDNA and RBP2 gene phylogenies. Mycological Research 111: 1268-1276.

Whitton SR, McKenzie EH, Hyde KD (2012) List of fungi associated with Pandanaceae. In: Fungi Associated with Pandanaceae (SR Whitton, EH McKenzie \& KD Hyde KD, eds): 355-428. Dordrecht: Springer. 